\title{
PENINGKATAN KUALITAS PUBLIKASI ILMIAH DAN PENELITIAN BAGI GURU SMA MELALUI PELATIHAN PEMANFAATAN SOFTWARE ZOTERO
}

\author{
Kusumawati Dwiningsih ${ }^{1}$, Tukiran $^{2}$, dan I Gusti Made Sanjaya ${ }^{3}$ \\ 1,2,3 Jurusan Kimia FMIPA Universitas Negeri Surabaya \\ email: ${ }^{1}$ kusumawatidwiningsih@unesa.ac.id \\ tukiran@unesa.ac.id \\ igmass@gmail.com
}

\begin{abstract}
Abstrak
Kegiatan Pengabdian Pada Masyarakat (PKM) ini bertujuan untuk melaksanakan pelatihan teknik penyusunan karya tulis ilmiah dan pengelolaan referensi menggunakan aplikasi Zotero dalam penulisan karya ilmiah. Sasaran kegiatan ini adalah guru-guru MGMP Kimia di Kabupaten Blitar. Kegiatan pelatihan dan pendampingan terdiri dari teori dan praktek dengan komposisi $30 \%$ untuk teori dan $70 \%$ untuk praktek, sementara mekanisme kegiatan workshop mencakup tahap persiapan, tahap seminar, dan tahap pelatihan. Berdasarkan kegiatan yang telah dilakukan, diperoleh hasil bahwa pelaksanaan PKM berjalan dengan baik dan lancar, dilihat dari fakta sebagian besar peserta cukup mampu mengaplikasikan Zotero dalam membuat kutipan karya tulis ilmiah serta antusias peserta menunjukkan antusias yang tinggi.
\end{abstract}

Kata kunci: Teknik penyusunan karya tulis ilmiah, pengelolaan referensi, aplikasi Zotero, MGMP Blitar

\begin{abstract}
This social responsibility (PKM) activity aims to carry out technical training in the preparation of scientific paper and reference management using the Zotero application in writing scientific paper. This activity is applied to the association of Chemistry teachers in Blitar District. The training and mentoring activities consisted of theory and practice with a composition of $30 \%$ for theory and $70 \%$ for practice, while the mechanism of the workshop activities included preparation, the seminar, and the training phases. Based on the activities carried out, the results show that the implementation of this social responsibilituy activity went well and smoothly, judging from the fact that most participants were quite able to apply Zotero in making excerpts of scientific paper and enthusiastic participants showed high enthusiasm.
\end{abstract}

Keyword: scientific works making technique, managing reference, Zotero application

\section{PENDAHULUAN}

Guru adalah jabatan profesi sehingga seorang guru harus mampu melaksanakan tugasnya secara profesional. Seseorang dianggap profesional apabila mampu mengerjakan tugasnya dengan selalu berpegang teguh pada etika kerja, independen (bebas dari tekanan pihak luar), cepat (produktif), tepat (efektif), efisien dan inovatif serta didasarkan pada prinsip-prinsip pelayanan prima yang didasarkan pada unsur-unsur ilmu atau teori yang sistematis, kewenangan profesional, pengakuan masyarakat, dan kode etik yang regulative (Marijan, 2012).

Pengembangan profesi guru menempatkan kegiatan guru dalam rangka pengamalan ilmu pengetahuan, teknologi dan keterampilan untuk peningkatan mutu baik bagi proses belajar mengajar dan profesionalisme tenaga kependidikan lainnya maupun dalam rangka menghasilkan sesuatu yang bermanfaat bagi pendidikan dan kebudayaan (Noorjannah, 2014).

Jika mencermati peraturan perundangan yang ada, utamanya Peraturan Menteri Negara Pendayagunaan Aparatur Negara dan Reformasi Birokrasi Nomor 16 Tahun 2009 tentang Jabatan Fungsional Guru dan Angka Kreditnya, sangat eksplisit bahwa guru berkewajiban untuk selalu melakukan pengembangan profesi. Pengembangan yang dimaksudkan berupa pengembangan keprofesian berkelanjutan. Secara eksplisit meliputi: 1) membuat karya tulis/karya ilmiah di bidang pendidikan, 2) menemukan teknologi di bidang pendidikan, 
3) membuat alat pelajaran/alat peraga atau alat bimbingan, dan 4) menciptakan karya tulis ilmiah, dan mengikuti kegiatan pengembangan kurikulum (PermenPAN, 2010).

Berdasarkan aturan diatas, menulis karya ilmiah merupakan syarat mutlak bagi guru yang menghendaki kenaikan pangkat dan golongan tertentu. Namun demikian fakta di lapangan menunjukkan bahwa pembuatan karya tulis ilmiah di kalangan guru masih sangat terbatas (Yulhendri, Marna, \& Oknaryana, 2018).

Surantini (2016) menyatakan, saat ini sekitar 390.000 guru berpangkat IV a masih mengalami kesulitan untuk kenaikan pangkat karena adanya persyaratan menulis karya tulis ilmiah. Kesulitan ini dilatarbelakangi oleh kurangnya kemampuan serta pengetahuan guru terkait dengan penulisan karya ilmiah. Faktor lain adalah kesulitan guru dalam menemukan ide/ gagasan yang akan diangkat menjadi suatu topik pada karya ilmiah.

Sebuah fakta memprihatinkan, bahwa telah banyak ditemukan guru yang menggunakan PAK palsu untuk keperluan kenaikan pangkat dari IVa ke IVb karena belum mampu membuat karya tulis ilmiah (A., 2015). Sementara fakta lain mengatakan bahwa sebagian besar guru menyatakan cukup dan sudah puas sampai pada golongan IVa saja bagi mereka yang sudah mencapainya. Seorang guru, agar dapat naik ke tingkat/golongan Ivb diwajibkan menulis sebuah karya tulis ilmiah dan harus lulus dari penilaian peer reviewed (Setyarsih, Dwiningsih, \& Tukiran, 2017; Sukarno, 2016).

Berdasarkan fakta- fakta yang telah disebutkan diatas, tampak bahwa karya tulis belum sepenuhnya menjadi bagian yang wajib dari tupoksi seorang guru yang profesional. Penulis telah melakukan identifikasi terhadap sekolah mitra melalui wawancara dan observasi lapangan, utamanya terkait dengan masalah yang dihadapi guru dalam menulis karya ilmiah. Berdasarkan hasil identifikasi, diperoleh hasil bahwa guru memiliki keinginan untuk segera dilakukan suatu pelatihan teknik penulisan karya tulis ilmiah guna mempermudah dan mempercepat usulan kenaikan pangkat mereka. Selain itu, guru juga menganggap bahwa penting bagi mereka untuk diberikan pembekalan terkait pengetahuan dan keterampilan mengelola referensi. Dalam penulisan sebuah karya ilmiah, penyebutan sumber referensi yang menjadi rujukan adalah suatu keharusan untuk menghindari tindakan plagiarisme. Dilain pihak, keterbatasan kemampuan (pengetahuan) penulis dalam mengacu referenclng system dapat menjerumuskan kepada tindak plagiarisme yang tidak disengaja.

Saat ini, seiring dengan kemajuan teknologi informasi, banyak tersedia alat bantu yang memudahkan penulis dalam membuat sitasi dan daftar pustaka. Zotero adalah salah satu reference manager yang dapat digunakan secara gratis yang memudahkan penulis untuk mengelola sumber-sumber referensi yang dimiliki sebagai acuan dalam penulisan rujukan.

Zotero (baca: zoh-TAIR-oh) dikembangkan oleh Roy Rosenzweig Center for History and New Media dan dirancang untuk tujuan non-komersial dan berbasis pada platform open-source. Oleh karena itu, Zotero dapat diperoleh dan digunakan secara gratis. Zotero memiliki kemampuan untuk mendeteksi konten-konten yang tersedia di dalam laman sebuah web, dan menyimpannya ke dalam komputer sebagai perpustakaan (digital) pribadi hanya dengan satu kali klik.

Zotero mengumpulkan seluruh karya hasil penelitian yang dimiliki dalam sebuah interface yang mudah digunakan. Pengguna dapat menambahkan file PDF, gambar, audio, video, dan snapshot dari halaman web ke dalam Zotero. Zotero secara otomatis akan mengindeks konten teks lengkap dari koleksi yang dimiliki atau ditambahkan ke dalam aplikasi. Zotero juga dilengkapi dengan kemampuan untuk menemukan apa yang dicari hanya dengan beberapa penekanan tombol.

Berdasarkan analisis situasi serta identifikasi terhadap permasalahan sekolah mitra, maka pelatihan penggunaan Zotero dapat menjadi kegiatan yang solutif dan perlu dilakukan. Dengan menggunakan aplikasi ini, penyimpanan artikel-artikel yang menjadi rujukan dalam penulisan karya ilmiah akan lebih mudah untuk ditemukan kembali. Lebih penting dari itu, aplikasi ini membantu anda untuk melakukan kutipan dari berbagai sumber informasi dengan menggunakan style yang dipilih. Aplikasi Zotero dapat mengutip dari satu sumber atau menggabungkan dari berbagai sumber untuk informasi yang sama. Semuanya dilakukan dengan mudah dan otomatis.

Disamping itu, aplikasi ini juga dapat menyajikan seluruh daftar bibliografi yang digunakan dalam karya tulis hanya dengan 
sekali perintah. Selanjutnya, aplikasi akan bekerja secara otomatis dan tidak perlu repotrepot untuk mengedit daftar bacaan ketika mengedit sitasi (kutipan) didalam artikel. Dengan demikian, bagian yang 'menyebalkan' dalam proses penulisan karya tulis ilmiah dapat menjadi mudah.

Dengan pelatihan pengelolaan efensi dengan menggunakan zotero diharapakan pengetahuan, pemahaman dan pengalaman belajar secara mendalam mengenai bagaimana menulis yang baik dan benar serta cara memudahkan pengguna/ peneliti untuk me-manage kutipan menggunakan Zotero.

\section{METODE PELAKSANAAN}

Pelatihan penggunaan Zotero diupayakan berjalan/ berlangsung di sekolah mitra melalui pendanaan dari sumber dana BOPTN FMIPA Universitas Negeri Surabaya TA 2017. Adapun metode pendekatan yang ditawarkan untuk menyelesaikan permasalahan utama mitra, sesuai dengan yang telah disepakati bersama, adalah pendekatan partisipatif.

Sejalan dengan permasalahan yang telah diuraikan, maka kerangka pelaksanaan dan teknik pencapaian solusi yang ditawarkan dalam kegiatan pengabdian ini antara lain adalah dengan memberikan seminar dan pelatihan. Sosialisasi metode penelitian dan pelatihan diberikan kepada seluruh guru-guru MGMP Kimia di Kabupaten Blitar.

Kegiatan ini disusun secara sistematis dari tahap perencanaan hingga prosedur proyeksi hasil penelitian yaitu dalam bentuk laporan penelitian, atikel ilmiah dan publikasi. Diharapkan setiap guru dapat menggunakan/memanfaatkan perangkat berbantu komputer dalam tahap perencanaan hingga proyeksi hasil berupa publikasi ilmiah. Kegiatan pengabdian yang dilaksanakan di SMAN 1 Blitar. Peserta yang terlibat dalam kegiatan ini terdiri dari 20 guru yang berasal dari MGMP Kimia yang ada di Kabupaten Blitar.

Kegiatan pelatihan dan pendampingan yang terdiri dari teori dan praktek dengan komposisi $30 \%$ untuk teori dan $70 \%$ untuk praktek.
Adapun mekanisme kegiatan wokshop dilakukan sebagai berikut:

1. Tahap Persiapan, mencakup kegiatan menyiapkan Panduan/Pedoman pelatihan penggunaan Zotero dan menyiapkan suatu contoh penggunaan Zotero dalam penelitian yang didanai atau yang telah dimuat/publikasi pada suatu jurnal terakreditasi baik lokal, regional, dan/atau nasional bahkan internasional.

2. Tahap Seminar, yaitu memandu para peserta pelatihan dalam mempelajari dan memahami pelatihan penggunaan Zotero tersebut tahap demi tahap, dimana sebelumnya peserta sudah diberikan pedoman pelatihan penggunaan zotero. Pemberian materi sebelum pelatihan ini bertujuan agar peserta berkesempatan mempelajari dan memahami Zotero.

3. Tahap Pelatihan, yaitu memberikan informasi tentang aplikasi Zotero untuk pengelolaan referensi dan membekali peserta dengan pengetahuan dan keterampilan penguasaan pengelolaan referensi menggunakan aplikasi Zotero dalam penulisan karya ilmiah serta mendorong peserta untuk mengaplikasikan perangkat lunak Zotero dalam penulisan karya ilmiah.

Optimalisasi proses pembelajaran yang dicapai melalui pelatihan dan pendampingan dalam diskusi kelas diharapkan dapat mendorong dan memfasilitasi proses sharing pengalaman dan interaksi pelatihan penggunaan Zotero dengan para peserta. Dengan demikian, peserta akan lebih mudah dalam mengakumulasi pengetahuan, pemahaman, dan pengalaman belajar mereka dalam pelatihan penggunaan Zotero.

\section{HASIL DAN PEMBAHASAN}

Pelaksanaan kegiatan PKM yaitu pelatihan Zotero diklasifikasikan ke dalam tiga tahap, yaitu tahap persiapan, tahap seminar, dan tahap pelatihan.

\section{Tahap persiapan}

Tahap ini mencakup kegiatan menyiapkan materi pelatihan dan pendampingan yang mencakup: 1) menyiapkan aplikasi Zotero, dan 2) menyiapkan pedoman/teknik penggunaan Zotero. 

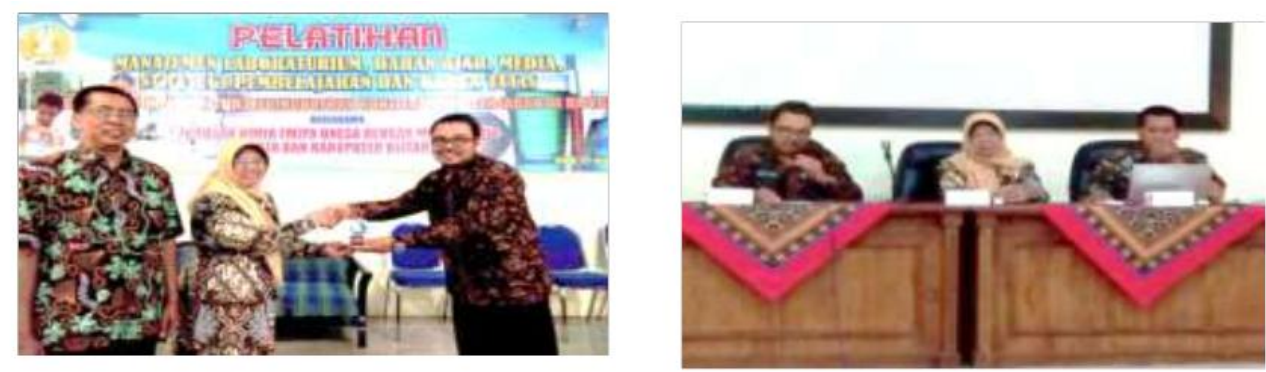

Gambar 1. Sambutan Ketua MGMP Kimia serta Pemberian Tali Asih
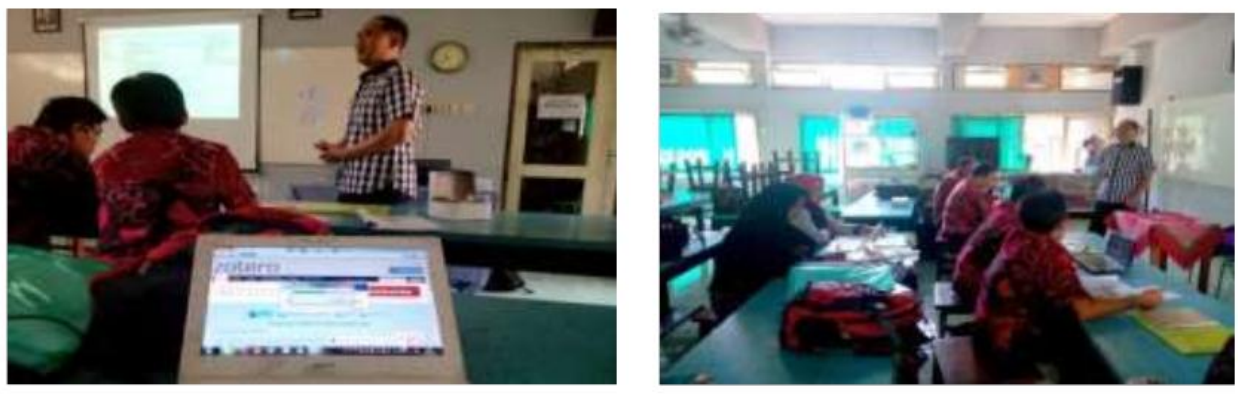

Gambar 2. Penyampaian Materi Pelatihan Diikuti Diskusi Hasil Pelatihan

\section{Zotero}

\section{Tahap Seminar}

Setelah semua materi pelatihan dan pendampingan disiapkan, berikutnya adalah penyampaian materi atau tahap seminar. Sebelum materi disampaikan oleh tim pelaksana PKM, diawali perkenalan tim pelaksana PKM ke para peserta oleh Ketua MGMP Kimia mitra dan diikuti kata sambutan. Setelah selesai, dilanjutkan penyampaian materi I oleh Prof. Dr. Tukiran, M.Si. yang meliputi: Pentingnya Karya IImiah Bagi Guru, Artikel IImiah dalam Jurnal IImiah, dan diikuti diskusi dan tanya jawab. Penyampaian materi II disampaikan oleh Kusumawati Dwiningsih, S.Pd., M.Pd mengenai tentang aplikasi yang digunakan sebagai bahan rujukan dan penyampaian materi Utama disampaikan oleh Dr. IGM Sanjaya, M.Si. mengenai cara pengutipan rujukan menggunakan Zotero, yang diikuti sesi diskusi dan tanya jawab, serta diakhiri pemberian tugas penyusunan artikel beserta cara mengutip dengan menggunakan Zotero secara individu, seperti terlihat pada Gambar 1 dan Gambar 2. Sebagaimana dilaporkan bahwa saat sebelum penyampaian materi oleh tim pelaksana PKM, tim PKM sudah menyampaikan pesan pada para peserta masing-masing sekolah mitra melalui Ketua MGMP Kimia yang diharapkan sudah menyusun draft artikel ilmiah, sehingga saat penyampaian materi bisa dilakukan diskusi penggunaan software Zotero.

\section{Tahap Pelatihan}

Pada tahap pelatihan dan pendampingan penulisan artikel ilmiah, selanjutnya menggunakan software referensi Zotero yang digunakan dalam pencarian, penyusunan artikel rujukan serta teknik pengutipan.

Tahap pendampingan penulisan artikel ilmiah dimulai dari sosialisasi prosedur memulai dan penggunaan aplikasi referensi Zotero. Setelah pelatihan guru diberi kesempatan untuk mula menulis rancangan artikel ilmiah.

Penggunaan Zotero ini diharapkan ada diskusi dan tanya jawab yang intens dan pelatihan penggunaan Zotero dari peserta terkait isi atau substansi materi pelatihan penggunaan Zotero yang mereka siapkan. Karena waktu pelatihan dan pendampingan pelatihan penggunaan Zotero dalam satu hari cukup pendek (3-4 jam) ditengah tengah kesibukan peserta dalam mengajar dan lain sebagainya, maka bisa dikerjakan dan dilanjutkan secara individu di rumah. Jika belum selesai juga akan menjadi tugas peserta yang harus ditagih pada pertemuan berikutnya. Dengan kata lain, sekalipun belum semua peserta mampu menyelesaikan pelatihan penggunaan Zotero di awal pertemuan, tetapi tetap memiliki tanggung jawab untuk melengkapinya hingga kegiatan PKM selesai. Namun, berkat dorongan dan motivasi dari tim pelaksana PKM dan kepala sekolah mitra, peserta mampu menyusun dan 
dapat dikompilasi draft pelatihan penggunaan Zotero peserta.

Setelah kegiatan pelatihan dan pendampingan selesai dilakukan, peserta diberikan lembar angket respon terhadap pelaksanaan PKM. Hal ini bertujuan untuk melihat sejauh mana kegiatan tersebut dikatakan telah berjalan dengan baik serta telah mampu memberikan pemahaman dan penguatan akan penggunaan Zotero bagi peserta. Aspekaspek pada angket respon yang ditanyakan kepada peserta didasarkan pada skala likert dan pertanyaan terbuka.

Angket respon bertujuan untuk melihat sejauh mana kegiatan tersebut dikatakan telah berjalan dengan baik serta telah mampu memberikan pemahaman dan penguatan akan pelatihan penggunaan Zotero bagi peserta. Angket respon ini terdiri dari 10 pertanyaan, dimana 6 pertanyaan merupakan pertanyaan terkait dengan pemahaman peserta, serta 4 pertanyaan lain berkaitan dengan respon peserta terhadap program pelatihan.

Berdasarkan angket respon tersebut, dapat disimpulkan bahwa aplikasi Zotero merupakan hal baru bagi responden/ peserta pelatihan. Hal ini dibuktikan dengan persentase responden yang tidak mengenal Zotero sebanyak $100 \%$. Hasil persentase ini dikategorikan yaitu sebanyak $87,5 \%$ responden belum pernah tahu mengenai aplikasi Zotero dan sebanyak 12,5\% menyatakan mengenal aplikasi lainnya yaitu Reference program yang disediakan microsoft word. Pada pertanyaan terkait manfaat Zotero, sebanyak $80 \%$ responden menyatakan bahwa Zotero bermanfaat dalam pembuatan bahan rujukan. Sementara lainnya $(20 \%)$ beranggapan bahwa Zotero bermanfaat dalam memperlancar tugas guru dalam kegiatan belajar mengajar dan penilaian. Terkait dengan pehamaham responden, sebelum dilakukan pelatihan, sebanyak $100 \%$ berpendapat bahwa tingkat pemahaman mereka kurang. Adapun setelah mengikuti pelatihan, sebanyak $40 \%$ responden menyatakan terjadi pergeseran pemahaman dari "kurang" menjadi "baik". $40 \%$ responden lain menyatakan cukup baik, sementara $20 \%$ responden masih merasa kurang paham.

Pertanyaan lain mengenai respon terhadap program pelatihan, menunjukkan fakta bahwa materi pelatihan yang diadakan merupakan hal baru (100\%). Berkaitan dengan keefektifan materi yang diberikan dalam membantu guru/responden dalam melaksanakan tugas, sebanyak $70 \%$ menyatakan bahwa materi tersebut sangat membantu, adapun 30\% lainnya berpendapat materi tersebut cukup membantu. Untuk keefektifan pelatihan, sebanyak $40 \%$ menyatakan pelatihan sangat efektif, $30 \%$ responden menyatakan cukup efektif, $20 \%$ responden menyatakan kurang efektif, dan sisanya $(10 \%)$ menyatakan tidak efektif. Jawaban responden terkait keefektifan pelatihan disebabkan karena sebagian besar responden merasa durasi pelatihan yang dilaksanakan masih kurang, sementara materi dan tugas yang diberikan cukup banyak. Hal ini didukung fakta hasil angket respon, dimana sebanyak $70 \%$ berpendapat waktu pelatihan kurang, sementara responden lain (30\%) berpendapat waktu yang diberikan telah cukup.

$$
\text { Berdasarkan observasi pada }
$$

pelaksanaan pelatihan Zotero, secara keseluruhan peserta pelatihan dapat mengikuti setiap tahap/sesi pelatihan dengan baik, namun kurang maksimal saat menyelesaikan tugas yang diberikan saat pelatihan Zotero. Sebagian peserta tidak dapat menyelesaikan tugas sesuai dengan batas waktu yang telah ditentukan. $\mathrm{Hal}$ ini dikarenakan peserta pelatihan menganggap bahwa waktu yang diberikan untuk menyelesaikan tugas cukup singkat. Walaupun tugas tersebut dapat diselesaikan secara individu di rumah, namun karena kurangnya pendampingan dan pemantauan secara kontinyu maka tugas yang diberikan tidak dapat diselesaikan oleh peserta dengan baik.

\section{SIMPULAN DAN SARAN}

\section{Simpulan}

Berdasarkan kegiatan yang telah dilakukan, diperoleh hasil bahwa pelaksanaan PKM berjalan dengan baik dan lancar, dilihat dari fakta sebagian besar peserta cukup mampu mengaplikasikan Zotero dalam membuat kutipan karya tulis ilmiah serta antusias peserta menunjukkan antusias yang tinggi.

\section{Saran}

Berdasarkan hasil observasi terhadap pelaksanaan kegiatan PKM, yaitu pelatihan penggunaan Zotero, maka penulis menyarankan agar pihak MGMP Kimia kabupaten Blitar lebih mendorong dan memotivasi agar guru mengikuti kegiatan 
PKM dengan sungguh-sungguh sehingga meningkatkan profesionalismenya, khususnya dalam pembuatan karya tulis ilmiah.

\section{DAFTAR PUSTAKA}

A., S. (2015). Harapan, Kenyataan dan Strategi Peningkatan Kemampuan Guru Dalam Penulisan Karya Tulis IImiah. In Prosiding Seminar Nasional Pengembangan Keprofesian menuju Guru Profesional (pp. 109-114). Universitas Negeri Malang.

Marijan. (2012). Cara Gampang Pengembangan Profesi Guru. Yogyakarta: Sabda Media.

Noorjannah, L. (2014). Pengembangan Profesionalisme Guru Melalui Penulisan Karya Tulis Ilmiah Bagi Guru Profesional Di Sma Negeri 1Kauman Kabupaten Tulungagung. Jurnal Humanity ISSN 0216-8995, 10(1), 100.

Peraturan Menteri Negara Pendayagunaan Aparatur Negara dan Reformasi Birokrasi Nomor 16 Tahun 2009 tentang Jabatan Fungsional Guru dan Angka Kreditnya (2010). Jakarta: Pendayagunaan, Kementerian Negara Birokrasi, Aparatur Negara dan Reformasi.

Setyarsih, W., Dwiningsih, K., \& Tukiran. (2017). Penyusunan Karya Tulis IImiah Bagi Guru Sman Di Kabupaten/ Kota Gresik. ABDI, 3(1), $22-31$.

Sukarno. (2016). Kendala dan Upaya Pengembangan Keprofesian Guru Sekolah Dasar Melalui Kegiatan Penulisan Karya IImiah. In Prosiding Seminar Nasional Inovasi Pendidikan Inovasi Pembelajaran Berbasis Karakter dalam Menghadapi Masyarakat Ekonomi ASEAN. Surakarta.

Surantini. (2016). Problematika Kompetensi Penulisan Karya IImiah Guru Sma Negeri 2 Muara Belitung. Widya Edukasi Jurnal Pendidikan Dan Tenaga Kependidikan, 1(1).
Yulhendri, Marna, J. E., \& Oknaryana. (2018). Analisis Kemampuan Menulis Karya Ilmiah Guru Ekonomi Di Kabupaten Pasaman Barat. Jurnal Inovasi Pendidikan Ekonomi, 8(1). 